\title{
Loss of Integrity: The True Failure of the Corporate Sector
}

\author{
Anona Armstrong and Ronald Francis \\ Victoria University, Australia
}

\begin{abstract}
Despite the introduction of legislation and corporate governance standards designed to promote business integrity, prosecution of the directors of many companies for fraud and other offences has continued. This paper describes the changing environment in which the members of the boards of companies operate, and their legal duties and responsibilities. The authors illustrate the traps for, and liabilities of, directors with reference to vignettes of three corporate investigations, Enron, HIH and more recently Opes Prime. This paper argues that, in many instances, the failures of the corporate sector were due to loss of integrity by the major actors. Whether this was related to a belief in their invulnerability, or whether a climate of fraud was seen as acceptable hard-nosed business practice is a moot point. An alternative point, that the collapses could be mediated by ignorance, or by malice, is a critical point, and one deserving of further investigation.
\end{abstract}

\section{Keywords}

Corporate Governance, Governance Standards, Corporate Integrity

\section{Introduction}

In recent memory, company after company has collapsed leaving a record of dubious (or creative) accounting practices, (plus those termed feral, i.e. designed to deceive, by Clarke, Dean and Oliver, 2003). This was combined with a lack of transparent and truthful reporting to the capital market.

One of the responses is the call for more stringent corporate governance with the result that there are a number of international research projects investigating a wide range of topics that include regulation, board performance, governance standards, legal structures, insolvency, accounting, auditing, corruption and ethics.

Current interest in these topics has been stimulated by some of the insights and developments that have emerged from inquiries into companies such as ENRON, ONE TEL, HIH and more recently Opes Prime. The resulting spate of convictions suggest that directors and office bearers (including internal and external auditors), are deficit in their knowledge of their duties and responsibilities, and good

Copyright (C) 2008 Victoria University. This document has been published as part of the Journal of Business Systems, Governance and Ethics in both online and print formats. Educational and non-profit institutions are granted a nonexclusive licence to utilise this document in whole or in part for personal or classroom use without fee, provided that correct attribution and citation are made and this copyright statement is reproduced. Any other usage is prohibited without the express permission of the governance practice.

The interest in corporate governance is often traced back to the $18^{\text {th }}$ Century ( refer to Beatty, 2006, for a review of its historical development) when companies under government patronage first began to conquer the 'new' world via the sea. Companies, such as the Dutch East India Company which operated out of Amsterdam from 1700, needed investors to band together so that sufficient capital could be 
raised for their venture, and also to share the risk. Apparently there were 70 members of the Dutch East India company board. About the same time, gossip around the town was focused on topics such as:

- Mismanagement at the biggest companies

- Insider trading

- Misstated profit and loss accounts

- Excessive remuneration of executives

- The need for accounting standards

- The need for independent directors

- Shredding of internal documents

They sound familiar! The Dutch East India Company eventually went under because of corruption. Nevertheless, it was not for nothing that it was said: fortunes were made 'when the ship came home'.

In the UK, during the middle Ages, the trade guilds and merchants' associations were the forerunners of companies. They existed as the beneficiary of some special right conferred by the Crown, such as the right or entitlement to control a particular trade. Subsequently, the establishment of a venture, with multiple members, required the issue of a Royal charter conferring on them the right to trade in a particular region.

Well known examples include the British East India Company and the Hudson's Bay Company operating in Canada. As incorporation required a Royal Charter, which was difficult to obtain, an alternative mechanism for business ventures was a "joint stock" company in which people were entitled to a share of the profit in proportion to their investment in the venture.

By the $18^{\text {th }}$ century there was a well developed market for shares in these ventures. However, speculation was rife. For example, shares in the South Sea Company rose from 100 pounds to 1000 pounds in a matter of days. The South Sea bubble collapsed in 1720 setting corporate development on hold for a century. It was such a calamity that it closed down parliament, directors of the company were arrested and their estates forfeited. In fact, for many years investing in private companies was regarded with suspicion. It was not until 1844 that corporate laws to regulate companies were formally introduced.

Australia was quick to follow suit and by 1850 the Australian States were introducing individual corporate regulation of private companies. By the 1880s, Australia was experiencing its first corporate boom.

A century later corporate history repeated itself. Connel, Bond and Skase, labeled the "corporate cowboys", were among those whose companies failed leaving shareholders with sizable losses. Companies that failed were: Ariadne, Qintex, Adstream, Budget, Tricontinental, Pyramid, State Banks in Victoria and South Australia. There were also rumbles at some of the major listed companies, Fosters, Westpac and Coles/Myer, all of which left shareholders feeling very uncertain.

By the 90s, the latest rash of collapses, that included $\mathrm{HIH}$ and OneTel, provided evidence that poor quality financial reporting was a major factor in the continued criticism of accounting and auditing practices following large, and often, unexpected corporate collapses. Indeed, prior to failure the accounts of many of those who failed had shortly before shown the companies to be profitable, and sometimes "highly successful" (Clarke, Dean and Oliver, 2003). Clarke et al (2003, p.22) put the position concisely '... . the failure of the publicly available financial information to disclose a true and fair view of companies' financial positions facilitated deception and in some cases exacerbated the losses'.

In the US the Sarbanes-Oxley Act and in Australia the CLERP Act 2004 were designed to strengthen financial reporting, oversee best practice guidelines for corporate governance and to oversee standards for accounting. 
Table 1. Major corporate disasters

\begin{tabular}{|c|c|c|}
\hline Company & Auditor & Shareholder loss \\
\hline Adelphia & Deloitte \& Touche & $\begin{array}{l}\text { Family used Adelphi credit to } \\
\text { purchase shares in the } \\
\text { company } \\
\$ 5.6 B\end{array}$ \\
\hline Enron & Arthur Anderson & $\begin{array}{l}\text { \$63B deficiency in } \\
\text { shareholder value }\end{array}$ \\
\hline Microstrategy & Pricewaterhouse Coopers & Revenue overstatement \\
\hline Waste Management & Arthur Anderson & $\begin{array}{l}\text { Revenue overstatement } \\
\$ 1.7 \mathrm{~B}\end{array}$ \\
\hline Worldcom & Arthur Anderson & $\begin{array}{l}\text { Capitalised US } \$ 3.9 \mathrm{~B} \text { in } \\
\text { operating costs } \\
\text { US } \$ 103 \mathrm{~b} \text { bankruptcy }\end{array}$ \\
\hline Xerox & KPMG & Revenue overstatement \\
\hline State Bank of SA & $\begin{array}{l}\text { KPMG Peat Marwick \& } \\
\text { Price Waterhouse }\end{array}$ & $\begin{array}{l}\text { Out-of-court settlement for } \\
\$ 120 \mathrm{~m} \text {. }\end{array}$ \\
\hline $\mathrm{HIH}$ & Arthur Anderson & Losses $: \$ 5.3 \mathrm{~B}$ \\
\hline
\end{tabular}

These failures, especially because they were often unexpected, raise serious questions about the extent to which company directors understand their duties and responsibilities and whether integrity is a value that is lost to the corporate sector.

\section{The Duties and Responsibilities of Directors and Officers}

All boards of registered companies must comply with the Australian Corporations and Securities Legislation, 2001 and the subsequent provisions of the Corporate Law Economic Reform Program (CLERP) issues 1 to 9. The Act is a mixture of both common law and statutory law. Note that the provisions of the Law in regard to duties apply to both directors and officers. The term 'officer' applies to anyone participating in decisions on behalf of a company that affect the business, its financial standing or with whose instructions the directors are accustomed to act. Corporate governance guidelines are intended to complement the law and support the ethical conduct of business leaders.

\section{Corporate Governance}

Governance is essentially concerned with the structures and processes for decision-making, accountability, control and behaviour at the top of organisations(Armstrong and Francis 2004b; Armstrong and Francis 2004a). Standards for good practice in governance have been introduced by Standards Australia (Standards Australia 2003a; Standards Australia 2003d) and Guidelines by the Australian Securities Exchange (Australian Securities Exchange 2003). In both cases, there is an emphasis on the values and ethics that should underlie corporate behaviour. Among the values that support the good governance principles are transparency, accountability, fairness, honesty and integrity (Francis 2000). As the ASX (2003) states p.3 'There is a basic need for integrity among those who can influence a company's strategy and financial performance, together with responsible and ethical decision-making'.

This paper argues that the conduct in the following three cases raises questions about the success of legislation and governance guidelines in achieving integrity in the business community. 


\section{Compliance with Legislation}

The following addresses five of major duties of the members of boards and then discusses how they were breached by the officers of ENRON and HIH. Similar duties may be found in corporation laws and in governance codes in most countries and are reflected internationally in the $\operatorname{OECD}(1999,2001)$ governance guidelines.

1. The duty to act (honestly) in good faith in the best interests of the corporation and for a proper purpose (Section 184 of the (Australian Corporations and Securities Legislation 2001)

Directors hold a position of trust, i.e. they owe a fiduciary duty to their company. They must act in what they honestly believe to be in the interests of the company and exercise their powers for the purpose for which they were conferred. They cannot, for example, as the Family did in the case of Adelphi, use credit lines for the company to purchase shares ( $\$ 5.6$ billion worth) in the company for the family.

An act of dishonesty includes making a statement that is false or misleading. It is not necessary to show that the false information actually affected the market place or that the information was issued with fraudulent intent. A civil penalty may require compensation to the company for an offence committed where a director was dishonest. Being intentionally dishonest or reckless is a criminal offence.

Jeffrey Lucy (2006), then Chairman of ASIC, defined 'reckless' as being aware of substantial risk and proceeding with a transaction where it is not justifiable and being indifferent to the consequences.

2. duty to avoid conflict in the position of a director and/or any interest that a director may have (S191)

Directors must not vote on matters in which they have a personal interest, disclose any interests in a contract with the company, and disclose any secret commissions. If a director does have a conflict of interest, the safest course of action is disclosure in writing at a board meeting and, of course, refraining from voting on the issue, and even absenting themself from the meeting while the issue is discussed.

\section{3. duties which prohibit the misuse of a director's position or information (S183)}

This duty requires members to respect the confidentiality of the board papers and discussion, and not to cause detriment to the company or use information to gain an advantage for themselves, such as engaging in insider trading.

Officers or any employees of a company may not use their position (S182) or information to gain an advantage for themselves or to cause detriment to the corporation (S183) nor can they use knowledge gained within a company to set up in competition or place themselves in a position where their personal interests are in conflict (i.e. where their powers are restrained) This commonly arises in cases of hostile takeovers. This means, for example, that members may not allocate new shares simply to safeguard their own positions and maintain control of a company.

\section{Table 2. Duties of Directors and Officers of Corporations: Specify the Act}

Duty to act (honestly) in good faith in the best interests of the corporation and for a proper purpose (Section 184).

Duty to act with care, diligence and skill (S180)

Duty to avoid conflict in the position of a director and/or any interest that a director may have(S191)

Duties which prohibit the misuse of a director's position or information (S183)

Duty to prevent a company trading while it is insolvent (S588G) 


\section{4. duty to act in good faith with care, diligence and skill (S 180)}

Gone are the days when the director arrived late for a Board Meeting, slept through the agenda and enjoyed a good lunch before going home. Under the Corporations Law members are required to devote the time necessary to prepare for meetings, actively participate in the board's work and have an adequate level of knowledge and skills.

In assessing whether a person has met their duty of care, diligence and skill, a judge will assess whether an officer of a corporation has acted honestly in the best interests of the corporation and exercised the degree of care and skill that another person, in a like position, would be expected to exercise in a similar situation.

\section{Duty to prevent a company trading while it is insolvent (S588G)}

Section $588 \mathrm{G}$ of the Corporations Act 2001 places a duty upon directors to prevent their company trading while it is insolvent.

Directors are personally liable for debts if a company trades while insolvent, becomes insolvent because of a debt or there are reasonable grounds for suspecting that a company is or would become insolvent.

In the case of insolvency, an administrator may be required to investigate the past conduct of the officers of a company. Compensation may be recovered for the benefit of creditors or the officers may be liable for prosecution if they have contravened the Companies Law by trading while insolvent or incurring a debt that causes the company to become insolvent. The criteria is if there were grounds for suspecting that the company was insolvent or a reasonable person is a like position in a company, in the company's circumstances, would be aware that a company was insolvent.

When judging whether or not a company is able to pay its debts, a court would look at what a director would be expected to know, i.e. they should be familiar with the operations of the entity and informed about its financial status. Being ignorant is not an excuse for failing to exercise due diligence or issues shares or trade while insolvent.

However, directors are not liable for honest errors of judgement and are protected by the Business Judgment Rule (S180.2) which refers to decisions in respect to its business operations. A defence is that a director informed themselves, and decisions which were made in good faith, and the best interests of the corporation.

Additional offences connected with liquidation are for an officer to:

- Fail to disclose or to deliver up company property

- Fraudulently deal with the company's books fraudulently obtain property for the company on credit or dispose of company property obtained on credit

- Fraudulently make a material omission in a report as to the company's affairs

- Prevent the production of the company books to the liquidator

- Falsely deal with the company's books

How were these duties met, or breached, in the case of Enron and HIH?

\section{ENRON}

Enron was formed in 1985 by a merger between two state-based natural gas companies, its main activity being to operate interstate gas pipelines. Its early share price reflected these beginnings and it was not until the early 1990 s that its share price nearly doubled to US\$20. It then began a meteoric rise to peak at US\$89 in the mid to late 90s. Only a year later the share price would dive to under US\$1 (Clarke, Dean and Oliver 2003)(Clarke et al 2003). According to Clarke et al, a new phrase was coined "Enronitis" referring to the securities market's loss of confidence due to concerns that accounting practices were being abused and that the market was not being fully informed. 
At its peak, Enron was the seventh largest listed company in the US. It had been diversified and transformed into a major conglomerate with e-business such as Enron on-line, hundreds of subsidiary and other related entities, numerous limited liability partnerships and SPEs (Special Purpose Entities). What went wrong?

In their review if the collapse, Clarke et al (2003) concluded that it was its inability to service its debt. It then bent the accounting rules and made use of SPEs (special purpose entities) to keep debt off the group consolidated balance sheet and to hide numerous losses. Another factor was the so called markto-model estimations of profits on future contracts. The computer model estimates, recorded on the balance sheet as profits earned, allowed ENRON to borrow externally. "When the contracts fell over, so did the SPEs and in sequence, ENRON" (p.261).

The directors failed in all the above directors' duties of care and diligence, operating in the best interests of the corporation, avoiding conflicts of interest and trading while insolvent. In 2002 The Justice Department opened a criminal investigation and the Chief Financial Officer, Andrew Fastow was indicted on 78 charges of conspiracy, fraud, money laundering and other counts (Table 3; The AGE 2006). His wife was also charged. He subsequently agreed to 10 years in prison and to forfeit $\$ 23.8$ million with his wife serving only one year so that she could take care of their children. Jeffrey Skilling, the CEO, was sentenced to 24 years and fined \$59 million for fraud, conspiracy and insider trading.

Table 3. Events at ENRON

\begin{tabular}{|c|c|}
\hline Date & Event \\
\hline 1996 & Jeffrey Skilling became Enron's president and chief operating officer \\
\hline Feb 12, 2001 & Jeffrey Skilling became Chief Executive \\
\hline \multirow[t]{2}{*}{ August14, 2001} & Skilling resigns citing personal reasons \\
\hline & Kenneth Lay returns to chief executive job \\
\hline October 22, 2001 & $\begin{array}{l}\text { Enron admits that the Securities and Exchange Commission is looking at } \\
\text { possible conflict of interest between Enron and its partnerships }\end{array}$ \\
\hline October 24, 2001 & Enron sacks Chief financial officer Andrew Fastow \\
\hline November 29, 2001 & SEC investigation is extended to cover Arthur Anderson \\
\hline December 2, 2001 & Enron files for bankruptcy \\
\hline December 3, 2001 & Enron lays off 4000 employees \\
\hline January 9, 2002 & The Justice Department opens a criminal investigation of Enron \\
\hline January 17,2002 & Enron fires Arthur Anderson blaming the auditor for destroying documents \\
\hline January 14, 2002 & Lay resigns \\
\hline March 14, 2002 & Arthur Anderson indicted for obstruction of justice \\
\hline August 31, 2002 & $\begin{array}{l}\text { Arthur Anderson surrenders licence to practice in the US; } 85,000 \text { people } \\
\text { lose jobs }\end{array}$ \\
\hline October 31, 2002 & $\begin{array}{l}\text { Andrew Fastow indicted on } 78 \text { charges of conspiracy, fraud, money } \\
\text { laundering and other counts }\end{array}$ \\
\hline May 1, 2003 & Fastow's wife Lea and seven former executives charged \\
\hline January 14, 2004 & $\begin{array}{l}\text { Andrew and Lea Fastow plead guilty. Fastow agrees to } 10 \text { years in prison } \\
\text { and to forfeit } \$ 23.8 \text { million. His wife serves one year. }\end{array}$ \\
\hline July 8, 2004 & Lay surrenders to FBI \\
\hline January 30,2005 & Trial of Lay and Skilling begins \\
\hline July 2006 & Lay dies of heart disease \\
\hline October 25, 2006 & $\begin{array}{l}\text { Skilling sentenced to } 24 \text { years and fined } \$ 59 \text { million for fraud, conspiracy } \\
\text { and insider trading }\end{array}$ \\
\hline
\end{tabular}

Source: The Age, October 25, 2006 Business 7

Remember those additional duties occurring during liquidation. Arthur Anderson, one of the biggest global accountancy firms was blamed for destroying documents. One of the Anderson accountants was reported as saying, during the Enron days, "Ship the Enron documents to the Feds", but his secretary heard "Rip the Enron documents to shreds". Andersons was indicted for obstruction and closed down. 
Being a partnership, even members of the firm in Australia were required to meet the firm's debts. Andersons was also the auditor for $\mathrm{HIH}$.

\section{HIH: the Biggest Collapse in Australian Corporate History}

We have seen how directors' duties were breached at Enron and the consequences for the company officers. Now, how were directors' duties addressed in the case of HIH? The final submission of the Counsel Assisting the HIH Royal Commission (Commission 2003) suggested that there might be over 1000 breeches of the law at HIH and FAI. I will touch on some of them.

$\mathrm{HIH}$ in 2000 was the second largest insurance company in Australia. Comprising over 240 separate companies, the HIH Group at one time operated in 16 countries including the UK, US, New Zealand, Hong Kong, Argentina, Malaysia, Sweden, Greece, Russia, Fiji, Papua New Guinea and the Philippines as well as Australia.

It was founded in 1968 by Ray Williams (and a colleague Michael Payne) who began his working life as a messenger boy with an insurance company when he was 14 . The British insurance company took over the company he founded in 1971 and the emerging entity, C.E. Heath International, listed on the Australian stock exchange in 1992 with a stock market capitalization of \$240 million.

In 1995 the company established a partnership with the Swiss insurer, Winterthur and HIH Winterthur was established. Five years later, in September 2000, Ray Williams resigned and in 2001 the company collapsed, shares were suspended and an administrator was appointed.

It was reported as the biggest corporate disaster in Australian history. A Royal Commission was appointed to inquire into the collapse of the company and to determine the extent to which actions of HIH's directors, officers, auditors, actuaries and advisors contributed to the failure of HIH. The Government then funded ASIC to establish a taskforce to investigate the referrals from the Commission.

Among the factors the Commission (Commission 2003) identified as contributing to HIH's problems were:

- Poor business decisions;

- hailstorms in Sydney;

- the acquisition of FAI insurances;

- failure of the auditors;

- failure of the actual financial outcomes to be reflected in the financial statements;

- failure of the regulators;

- the failure of the board to perform their duties.

To address the major issues here it is noted that:

\section{Business decisions}

Poor business decisions exposed the company to high risks such as marine insurance and film investments in the UK; and the Florida typhoon and overseas' workers compensation claims resulting from industry deregulation in California and altered court-awarded benefits in the US; and the acquisition of FAI insurance. 
Table 4. Key Directors and associates of HIH found guilty of not meeting their duties and responsibilities

\begin{tabular}{|c|c|c|c|}
\hline Name & Position & Failure in duties & Penalties \\
\hline Ray Williams & $\begin{array}{l}\text { Founder, } \\
\text { Chairman }\end{array}$ & $\begin{array}{l}\text { Reckless and failed to properly exercise } \\
\text { his powers and discharge his duties } \\
\text { for a proper purpose: } \\
\text { Party related transactions to prop up } \\
\text { share price } \\
\text { Signed a letter that was misleading } \\
\text { Authorized issue of a prospectus by } \\
\text { HIH that contained a material } \\
\text { omission } \\
\text { Made statements in the annual report } \\
\text { which he knew to be misleading that } \\
\text { overstated the operating prit*? before } \\
\text { abnormal items by } \$ 92.4 \mathrm{~m} \text {. }\end{array}$ & 4.1/2 years jail \\
\hline Rodney Adler & $\begin{array}{l}\text { FAI chairman } \\
\text { and MD, } \\
\text { director of } \\
\text { HIH }\end{array}$ & $\begin{array}{l}\text { Party related transactions to prop up } \\
\text { share price } \\
\text { Two charges of disseminating false } \\
\text { information to induce people to buy } \\
\text { HIH shares } \\
\text { Obtaining money by false statements } \\
\text { Failing to discharge his duties in good } \\
\text { faith and in the best interests of the } \\
\text { company (did not disclose conflicts of } \\
\text { interest to board) }\end{array}$ & $\begin{array}{l}4.1 / 2 \text { years jail } \\
\text { (nonparole } 2.1 / 2 \text { ) }\end{array}$ \\
\hline Bill Howard & $\begin{array}{l}\text { General } \\
\text { Manager of } \\
\text { HIH } \\
\text { Insurance, } \\
\text { Financial } \\
\text { Services and } \\
\text { Investment } \\
\text { Manager }\end{array}$ & $\begin{array}{l}\text { Dishonestly received from Brad Cooper } \\
\$ 124,000 \text { in return for facilitating } \\
\text { payments; } \\
\text { Facilitated payment of } \$ 737,000 \text { to } \\
\text { cooper knowing the debt had already } \\
\text { been discharged }\end{array}$ & $\begin{array}{l}3 \text { years jail } \\
\text { Suspended for } \\
\text { giving assistance } \\
\text { to the HIH } \\
\text { Investigation }\end{array}$ \\
\hline $\begin{array}{l}\text { Bradley } \\
\text { Cooper }\end{array}$ & Entrepreneur & $\begin{array}{l}6 \text { charges of bribing Howard to pay } \\
\text { false claims } \\
7 \text { charges publishing false and } \\
\text { misleading statement }\end{array}$ & 8 years jail \\
\hline
\end{tabular}

Courts do not usually hold directors accountable for poor business decisions. A Good Judgment Rule (S180(2)) provides some protection for officers provided that directors comply with their duties. If they have informed themselves about the subject-matter of the judgment, acted in good faith for a proper purpose and in the best interests of the company, and did not have a material personal interest in the outcomes, they will not be held accountable for poor decisions. However, note that despite this defence, the Act still requires a member of a board to act with care and diligence, to avoid conflict of interest and most importantly to act in the best interests of the company.

The purpose of the business judgment rule is to protect the authority of members of boards so that they are not constrained from making business decisions which contain a certain amount of risk but not to excuse them from negligence or fraud. 


\section{Acquisition of FAl: Failure to act with care, diligence and skill}

Deliberations in the HIH Royal Commission suggested that the acquisition of FAI and the practices that followed were the 'nail in the coffin' for HIH. Directors were accused of being negligent in their due diligence of FAI, and that it may, in fact, have been insolvent when acquired. HIH reported the purchase of FAI in 1999 for $\$ 300$ million.

Evidence at the Royal Commission suggested that the real value was nearer $\$ 100$ million rather than the \$300million recorded.

\section{Failure of the actual financial outcomes to be reflected in the financial statements}

Section 296 and 297 of the Act require the financial report to comply with accounting standards and to present a true and fair view of the financial position. The Annual Report following the acquisition of FAI reported a $112 \%$ rise in profits in the first half of 2000 . The reported increase in profits were said to be the due to the generally accepted, but dubious, accounting practices:

- The capitalization of expenses such as deferred acquisition costs,

- Deferred information technology costs,

- Bookkeeping debits such as future income and goodwill. Goodwill of FAI was recorded as $\$ 400$ million in the 2000 accounts, and not the $\$ 100$ million previously recorded.

\section{Failure of the auditors}

The audit opinion reported that the accounts gave a true and fair view of the company's financial performance, complied with the accounting standards and corporate regulations and other professional reporting requirements.

In the Notes to the Accounts of 30 June 2000, the auditors had provided an unqualified opinion in respect of the financial accounts showing a net profit of $\$ 939$ million. If it was operating with this much profit, how could it have collapsed only 9 months later?

\section{The regulators}

The assessment of solvency requires assessment of the capacity of an entity to meet its debts when they fall due. In an insurance company actuaries calculate the likelihood of future claims based on current financial data.

It appears that information about HIH's position was disputed on actuarial grounds and that this information was conveyed to the Australian Prudential Regulation Authority (APRA) (Clarke et al, 2006). No action was taken and the HIH Administrator, Tony McGrath, pursued a $\$ 5.6$ billion lawsuit against APRA claiming that the government and its prudential regulator were negligent in allowing $\mathrm{HIH}$ to collapse in March 2001.

\section{Failure of governance}

The minimum requirements for good governance practices demand independence of the board, audit committees composed of independent directors, independent external auditors and a reliable independent information and reporting system (Armstrong 2004a). How independent were the board members? Two of the board members were members of Andersons, the Auditing firm and had been members of the board from its earliest days. Further, the Chairman, Ray Williams, was a very dominating leader, even charismatic, and he dominated the board room. Clarke et al (2003) believed that the Board suffered from 'Groupthink ', a term used to describe a situation where peer pressures ensure that everyone votes the same way and are reluctant to express a differing opinion. 
Did the board accept that the auditors, Arthur Anderson, were actually independent or was there a conflict of interest? In addition to being on the board, and providing audit services, members of the Arthur Anderson firm had been providing other consulting services to the company.

Other questions were: When did the officers of the company know that the company was unable to meet its debts? Did they notify ASIC of changes in the financial position of the company and the impact on its share price? Did they trade while insolvent?

Listed companies are obliged to warn the market of material information that might impact on their share price. The HIH Board failed to publicly disclose its deteriorating financial position. In fact, the Chairman did the opposite, claiming in a letter to brokers that it was 'rock solid'. The unexpected collapse of HIH in 2001 with losses of $\$ 5.3$ billion defrauded not only investors, creditors and staff but all those who held policies with the company.

Not only was there a failure of the actual financial outcomes to be reflected in the financial statements but HIH's share price was propped up by a series of party-related transactions. A subsidiary of HIH, Pacific Eagles Equities, purchased $\$ 10$ million of $\mathrm{HIH}$ shares on-market. The directors were subsequently charged with using funds for an improper purpose.

Tony McGrath of KPMG in his report as provisional liquidator identified problems of "reckless management, incompetence, fraud, greed and self-dealing". In 2002, Ray Williams was disqualified as a director for 10 years and Rodney Adler for 20 years and both directors, and the finance director Dominic Federa received heavy fines, Williams $\$ 650,000$, Adler $\$ 450,000$ and Fedora $\$ 5,000$.

For recklessly failing to properly exercise his powers and discharge his duties for a proper purpose by authorizing a prospectus and an Annual Report that contained false information, Ray Williams was sentenced to four and a half years jail. Adler also received a similar sentence for issuing false information and not disclosing his conflict of interest. Brad Cooper received the heaviest sentence, eight years for 6 charges of bribing Bill Howard to pay false claims and seven charges of issuing false information.

Table 5. Creative accounting

\section{First tier}

Moving capital gains and losses in and out of the same statement

Accruing profits of related companies

Off-balance sheet financing

Transfer of assets between related companies

Second tier

Arrangements to reverse transactions after balance date

Pyramiding asset values through related-party transactions

Other

Tax effect accounting (deferred tax debits are included in profit and loss and balance sheets, FITB)

Recording beneficial effects of foreign exchange movements as part of operating profits or additions to reserves

Capitalising expenses as assets

Abnormal/extraordinary items classifications

Using debt and off-balance sheet financing in the form of derivatives

Source:(Bosch 1990)Bosch, 1990; Clarke et al, 2003

\section{What did Enron and HIH have in Common?}

We will comment on only three factors.

- First was incompetence of the leaders and their failure to meet their duties under the Act.

- Second was the use of creative accounting practices. 
- Third was the lack of ethics, honesty and integrity in the face of collapse

\section{The leaders}

Skilling was a Harvard graduate, Williams was a product of rising through the ranks to the top. Both seemed out of their depth in the face of the fast growth in the complexity and magnitude of their businesses. However, even if they were incompetent, their major crime was deliberate dishonesty and fraud.

Creative accounting practices are those which are not illegal but could be considered unethical. Feral accounting practices are those purposely designed to mislead (Clark et al, 2003).Some of the accounting practices (Table 5) used by both of these companies included moving capital gains and losses in and out of the same statement, accruing profits of related companies, off-balance sheet financing, transfer of assets between related companies. A major deception of shareholders was the blatant use of dubious estimates of potential future profits as collateral for loans.

Both companies ran into debt and could not meet their debts as they fell due. The directors failed not only in their business decisions but, in trying to conceal the problems, they also breached all of their duties as company directors. What made the directors totally disregard their ethical responsibilities? And what were the ethical stances of the professionals in the accounting firm?

\section{Opes Prime}

Reports of Opes Prime also suggest that dubious financial practices and a failure by the Directors and Officers to appreciate the unethical nature of some of their business practices led ultimately to the company's problems.

Newspapers reported that Opes Prime (Table 3) had used client funds for its own purposes, and experienced lack of disclosure and transparency, conflicts of interest, etc

Opes Prime is a stockbroking business which offered clients a facility for margin investment. Clients placed their shares with Opes Prime as security for a loan with which to invest in further shares in the market. While the share prices of these new shares went up, the value of the investment increased. When the share market fell, investors were called upon to provide additional funds to cover the margin between the former value of the shares and the new value.

Opes Prime bundled clients' shares into large packages and used these as security to borrow from ANZ and Merrill Lynch. The first difficulty arose because Opes Prime borrowed the full value of the shares clients deposited with them from the banks, but only lent a proportion of this back to the clients. The difference was then used by Opes Prime to speculate on hedge funds. This included short selling intended to manipulate the market.

When the market began to fall, a call was made by the banks to Opes Prime to meet the margin. Opes Prime did not have the funds to meet their proportion of the loan and then their clients discovered that the outstanding margin on their shares was much greater than they had been led to believe. Furthermore, many clients were unaware of the conditions of the contracts with Opes Prime. In many cases, OpesPrime had deposited the clients' shares and their control with the banks. Clients no longer had control of their shares many of which represented the assets of their own companies.

Warning bells went off in the banks which then found themselves owners of shares in a number of smaller companies whose owners were suddenly disenfranchised. They then began to unload the shares in order to safeguard their loans. This further depressed the market and increased the margin to be funded by clients, even if they could regain control of their shares. It was also reported that employees of the ANZ bank were among the OpesPrime margin lending clients. 
Table 3. Opes Prime events, directors' duties and ethical values underlying governance standards

\begin{tabular}{|c|c|c|}
\hline $\begin{array}{c}\text { Opes Prime } \\
\end{array}$ & Directors duties & Ethical Values \\
\hline $\begin{array}{l}\text { Borrowed funds secured by } \\
\text { clients' shares for its own } \\
\text { purposes }\end{array}$ & $\begin{array}{l}\text { Act in good faith and for a } \\
\text { proper purpose }\end{array}$ & Accountability \\
\hline $\begin{array}{l}\text { Lack of disclosure of terms } \\
\text { (Australian Market Securities } \\
\text { Lending Agreement, Sunday } \\
\text { Mail, } 6 \text { April, 2008) }\end{array}$ & Act with care and diligence & Transparency \\
\hline $\begin{array}{l}\text { Client shares lent out to hedge } \\
\text { fund managers for a fee }\end{array}$ & Avoid conflict of interest & Fairness and balance \\
\hline $\begin{array}{l}\text { Discrepancy between amount } \\
\text { borrowed and margin lending to } \\
\text { clients }\end{array}$ & & Integrity and Honesty \\
\hline $\begin{array}{l}\text { Bundled shares into large } \\
\text { packages and used as security to } \\
\text { borrow from ANZ, Merrill } \\
\text { Lynch }\end{array}$ & & Dignity \\
\hline $\begin{array}{l}\text { Accepted higher loan-to-value } \\
\text { ratios and riskier shares as } \\
\text { security }\end{array}$ & & Legal compliance \\
\hline $\begin{array}{l}\text { Did not keep separate client } \\
\text { accounts }\end{array}$ & & Good will \\
\hline \multicolumn{3}{|l|}{$\begin{array}{l}\text { Short sold shares to force prices } \\
\text { down }\end{array}$} \\
\hline \multicolumn{3}{|l|}{$\begin{array}{l}\text { Failed to make margin calls on } \\
\text { major and strategic clients, } \\
\text { moved stock to and from these } \\
\text { accounts to cover margin calls } \\
\text { (The Age April 5, 2008, } \\
\text { Business p.6) }\end{array}$} \\
\hline $\begin{array}{l}\text { Included employees of ANZ } \\
\text { among margin lending } \\
\text { clients(Australian, } 27 \text { April, } \\
\text { 2008) }\end{array}$ & & \\
\hline $\begin{array}{l}\text { ANZ/Merrill Lynch sell the shares } \\
\text { Opes used to secure funding }\end{array}$ & & \\
\hline
\end{tabular}

A number of court cases are pending and the issues are yet to be resolved. However, as Table 3 suggests, directors and officers of the company appear to have disregarded directors' duties including acting in good faith and for a proper purpose, executing these duties with care and diligence and avoiding conflicts of interest. The ethical issues of transparency, accountability and honesty and integrity are not in evidence.

\section{Conclusion}

In the above cases were the duties of directors blatantly disregarded, or not understood? Or do values such as accountability, fairness, honesty and integrity, which underlie the principles of good corporate governance no longer have currency in the modern corporate world?

Knowing and practicing the ethical principles underlying corporate governance is the first step in safely negotiating directors duties and responsibilities. Lawyers and others advocate further governance regulation and compliance to prevent people from being dishonest. Further regulation may not be the 
answer. An alternative, perhaps, is that demonstrating knowledge of community values and ethics should be an integral part of the qualifications for company directors and officers.

What is most obvious here is that the failure to accommodate the ethical dimension of business has disastrous consequences. Corporates fail, directors are imprisoned, and the reputation of business is besmirched. Put at its bluntest, bad ethics is poor risk management. Regulation and compliance have a proper and powerful place: so too does the climate of ethical dealing.

\section{References}

Armstrong, A. (2004). Corporate governance standards: intangibles and their tangible value. Australian Journal of Corporate Law pp. 97-110.

Armstrong, A. and R. Francis (2004). Applications of Corporate Governance. Sydney, Standards Australia International.

Armstrong, A. and R. Francis (2004). Introduction to Corporate Governance. Sydney, Standards Australia International.

Australian Corporations and Securities Legislation, A. (2001). 2001 Corporations Law. Sydney, CCH Australia Ltd.

Australian Securities Exchange, A. (2003). "Principles of good Corporate Governance and Best Practice Recommendations." 2003, from www.asx.com.au/corporategovernance.

Beatty, R. (2006). Presentation. Australian Institute of Company Directors. Port Douglas, AICD..

Bosch, H. (1990). The Workings of a Watchdog. Melbourne, William Heinemann, Australia.

Clarke, F., G. Dean, et al. (2003). Corporate collapse: accounting, regulatory and ethical failure. Cambridge, Cambridge University Press.

Francis, R. (2000). Ethics and Corporate Governance: an Australian Handbook. Sydney, University of New South Wales.

HIH Royal Commission (2003) HIH Royal Commission Final Report., Canberra, Government of Australia.

Lucy, J. (2006). Directors' Responsibilities:Reality vs the Myths. A speech by ASIC Chairman Jeffrey Lucy to the Australian Institute of Company Directors, 17 August 2006, . Melbourne.

OECD, Organisaion for Economic and . Community Development. (1999). "Principles of Corporate Goverancance." Accessed May 30, 2001, from www.oecd.org/daf/governance/principles.htm.

OECD, Organisaion for Economic and . Community Development (2001) Guidelines for Multinational Enterprises." Accessed May 30, 2001, from http://www.oecd.org//daf/investment/guidelines/mntext.htm.

Standards Australia International (2003d). Australian Standard: Corporate Governance AS 8000-2004 Sydney, Standards Australia.

Sunday Mail, Australian Market Securities Lending Agreement, 6 April, 2008

The Age (2008) April 5, 2008, Business 6

The Age (2006) October 25, 2006 Sentenced to 24 years, Skilling Protests, Business 7

The Australian, (2008) 27 April, 2008, p.31. 
